\title{
PERANAN CORPORATE SOCIAL RESPONSIBILITY TERHADAP REPUTASI PERUSAHAAN PADA PT SEMEN TONASA
}

\author{
Sumatriani ${ }^{1}$, Dian Pane ${ }^{2}$, Nurhasana Kamaruddin ${ }^{3}$ \\ ${ }^{1,2}$ Dosen Jurusan Administrasi Niaga, Politeknik Negeri Ujung Pandang \\ ${ }^{3}$ Mahasiswa Jurusan Administrasi Niaga, Politeknik Negeri Ujung Pandang \\ Sumatrianitri@yahoo.com
}

\begin{abstract}
ABSTRAK
Penelitian ini dilakukan pada masyarakat sekitar pabrik PT Semen Tonasa, yakni Desa Biring Ere, Kecamatan Bungoro, Kabupaten Pangkajene dan Kepulauan yang dipilih dengan menggunakan teknik purposive sampling sehingga menghasilkan sampel sebanyak 97 responden. Permasalahan pada penelitian ini yakni kegiatan operasional pabrik dan truk perusahaan mengeluarkan debu yang beterbangan di udara dan menempel di rumah-rumah masyarakat, sehingga hal tersebut mengotori lingkungan dan menyebabkan pencemaran udara dan dapat berdampak buruk pada kesehatan seperti penyakit pernafasan. Selain itu, aksi unjuk rasa pada Oktober 2019 silam merupakan bentuk kekecewaan masyarakat yang tuntutannya ketika audiensi belum ditanggapi. Karena itu, penelitian ini bertujuan untuk, 1) mengetahui persepsi masyarakat terhadap implementasi corporate social responsibility pada PT Semen Tonasa; 2) mengetahui persepsi masyarakat terhadap reputasi perusahaan pada PT Semen Tonasa; 3) mengetahui pengaruh implementasi corporate social responsibility terhadap reputasi perusahaan pada PT Semen Tonasa.

Pengumpulan data dilakukan dengan kuesioner yang valid dan reliabel. Hasil analisis statistik deskriptif diperoleh bahwa nilai variabel implementasi corporate social responsibility sebesar 4,06 dan reputasi perusahaan sebesar 4,01 yang masing-masing berada pada kategori baik. Hasil analisis statistik inferensial menunjukkan bahwa implementasi corporate social responsibility berpengaruh signifikan dan positif terhadap reputasi perusahaan pada PT. Semen Tonasa.
\end{abstract}

\section{Kata Kunci: CSR, reputasi perusahaan}

\begin{abstract}
This research was conducted on the community around the PT Semen Tonasa, it's Biring Ere Village, Bungoro Subdistrict, Pangkajene and Kepulauan Regency were selected using a purposive sampling technique so the sample were 97 respondents. The problem in this research was the operational activities of the factory and company trucks emit dust that flies in the air and sticks to people's homes, so that it pollutes the environment and causes air pollution and can have a negative impact on health such as respiratory disease. In addition, the demonstration in October 2019 was a form of public disappointment whose demands during the hearing had not been responded to. Therefore, this study aims to, 1) determine public perceptions of the implementation of corporate social responsibility at PT Semen Tonasa; 2) determine public perceptions of the company's reputation at PT Semen Tonasa; 3) determine the effect of the implementation of corporate social responsibility on the company's reputation at PT Semen Tonasa.

Data collection by a valid and reliable questionnaire. The results of descriptive statistical analysis showed that the value of the implementation of corporate social responsibility variable was 4.06 and the company's reputation was 4.01, each of which was in the good category. The results of inferential statistical analysis show that the implementation of corporate social responsibility has a significant and positive effect on the company's reputation at PT Semen Tonasa.
\end{abstract}

Keywords: CSR, company's reputation 


\section{PENDAHULUAN}

Maraknya pertumbuhan industri atau perusahaan hari ini tidak hanya akan memberi pengaruh positif seperti meningkatnya pertumbuhan ekonomi dengan bertambahnya lapangan pekerjaan khususnya bagi masyarakat sekitar perusahaan. Pada waktu yang bersamaan, pertumbuhan ini juga memiliki dampak negatif dari hasil kegiatan operasional perusahaan. Misalnya, pencemaran lingkungan dan adanya limbah perusahaan. Jadi, kembali lagi bahwa yang akan menerima dampak tersebut adalah masyarakat yang bermukim di sekitar tempat beroperasinya pabrik perusahaan. Hal ini tentu membuat perusahaan melanggar Pasal 9 Ayat 3 Undang-Undang Nomor 39 Tahun 1999 tentang Hak Asasi Manusia yang mengamanatkan bahwa lingkungan hidup yang baik dan sehat adalah hak setiap orang.

Menanggapi hal tersebut, selain menuntut penerapan tata kelola perusahaan yang baik atau yang biasa disebut dengan istilah good corporate governance (GCG) dengan tiga diantara prinsipnya adalah akuntabilitas (accountability), kesetaraan dan kewajaran (fairness), serta pertanggungjawaban (responsibility). Pemerintah juga mewajibkan perusahaan untuk melaksanakan tanggung jawab sosial lingkungan (TJSL) atau corporate social responsibility (CSR). Aturan ini mengacu pada amanat Undang-Undang Perseroan Terbatas (UUPT) yakni Nomor 40 Tahun 2007 Pasal 74 Ayat 1.

CSR merupakan salah satu dari tanggung jawab perusahaan kepada pihak yang mendapatkan pengaruh atas keberadaan perusahaan yang selanjutnya disebut sebagai pemangku kepentingan (stakeholders), salah satu diantaranya yakni masyarakat. Maka dari itu, perusahaan sudah seharusnya memiliki kesadaran sebagai bagian dari masyarakat dan bertanggung jawab kepadanya.

Reputasi perusahaan yang dimaksud ialah hasil akumulasi penilaian yang menggambarkan citra dan persepsi masyarakat mengenai perusahaan dari waktu ke waktu. Tentunya semua perusahaan menginginkan reputasi perusahaan yang baik, namun hal ini tergantung dari bagaimana perusahaan itu sendiri memberikan input dan pengelolaan yang baik dalam menghasilkan reputasi perusahaan yang baik pula.

Salah satu perseroan yang melaksanakan program CSR adalah PT Semen Tonasa. Badan Usaha Milik Negara (BUMN) ini harus senantiasa menjalankan aturan-aturan terkait pelaksanaan CSR dalam menangani segala dampak yang ditimbulkan akibat kegiatan operasional perseroaan. Program CSR perusahaan semen terbesar di kawasan Indonesia Timur ini dinamakan Program Tonasa Bersaudara dengan lima pilarnya yakni Tonasa Cerdas, Tonasa Mandiri, Tonasa Bersahaja, Tonasa Hijau, dan Tonasa Sehat.

Pengamatan dan wawancara awal penulis menunjukkan bahwa kegiatan operasional pabrik perusahaan mengeluarkan debu yang beterbangan di udara dan menempel di rumah-rumah masyarakat sekitar serta operasional mobil truk pengangkut bahan baku maupun semen juga menyebabkan debu di jalanan bertebaran, sehingga hal tersebut mengotori lingkungan dan menyebabkan polusi atau pencemaran udara. Hal ini dapat berdampak buruk pada kesehatan masyarakat Desa Biring Ere, seperti mengakibatkan penyakit pernafasan. Selain itu, masalah yang berkaitan juga pernah terjadi seperti yang tertulis dalam media pemberitaan online Kabar.News mengenai aksi sejumlah massa yang mengatasnamakan dirinya sebagai Pejuang Bangsa mengunjuk rasa di depan kantor pusat PT Semen Tonasa pada tanggal 14 Oktober 2019. Aksi tersebut merupakan bentuk kekecewaan setelah audiensi, namun pihak perusahaan tidak menanggapi tuntutan yang dimasukkan dalam surat audiensi, beberapa diantaranya yakni dampak lingkungan terhadap masyarakat sekitar perusahaan, penerimaan tenaga kerja yang tidak mengutamakan masyarakat lokal, dan kurangnya sosialisasi program kemitraan PT Semen Tonasa ke masyarakat lokal. 
Berdasarkan uraian tersebut, penulis tertarik melakukan penelitian dengan judul "Pengaruh Implementasi Corporate Social Responsibility terhadap Reputasi Perusahaan pada PT Semen Tonasa untuk melihat apakah implementasi CSR memberi pengaruh terhadap reputasi PT Semen Tonasa.

\section{TINJAUAN PUSTAKA}

\subsection{Implementasi Corporate Social Responsibility}

\subsubsection{Definisi Implementasi Corporate Social Responsibility}

Implementasi corporate social responsibility (CSR) atau yang biasa dikenal dengan tanggung jawab sosial perusahaan (TJSL) bukan lagi menjadi hal yang baru. Ada banyak ragam penafsiran terkait CSR, beberapa diantaranya seperti yang dinyatakan oleh Griffin dan Michael W. Pustay (2015:123) bahwa "Tanggung jawab sosial perusahaan (corporate social responsibilityCSR) adalah serangkaian tanggung jawab yang dilakukan perusahaan untuk melindungi dan mengangkat masyarakat di mana mereka berfungsi." Selanjutnya Fahmi (2017:81) memberikan definisi sebagai berikut.

"Corporate Social Responsibility adalah komitmen perusahaan atau dunia bisnis untuk berkontribusi dalam pengembangan ekonomi yang berkelanjutan dengan memperhatikan tanggung jawab sosial perusahaan dan menitikberatkan pada keseimbangan antara perhatian terhadap aspek ekonomis, sosial dan lingkungan.”

Pelaksanaan CSR tidak terlepas akan adanya ketentuan pemerintah dalam mengaturnya, seperti menurut pendapat Azheri (2012:28) sebagai berikut.

"CSR adalah sebagai komitmen perusahaan untuk melaksanakan kewajiban yang didasarkan atas keputusan untuk mengambil kebijakan dan tindakan dengan memerhatikan kepentingan para stakeholders dan lingkungan dimana perusahaan melakukan aktivitasnya yang berlandaskan pada ketentuan hukum yang berlaku."

Adapun aturan yang menyebutkan tentang definisi CSR salah satunya termuat dalam Undang-Undang tentang Perseroan Terbatas (UUPT) Nomor 40 Tahun 2007 Pasal 1 Ayat 3 yakni "Tanggung Jawab Sosial dan Lingkungan adalah komitmen perseroan untuk berperan serta dalam pembangunan ekonomi berkelanjutan guna meningkatkan kualitas kehidupan dan lingkungan yang bermanfaat, baik bagi perseroan sendiri, komunitas setempat, maupun masyarakat pada umumnya".

Dari beberapa definisi tersebut, penulis dapat menyimpulkan bahwa implementasi CSR adalah aktivitas tanggung jawab yang dilaksanakan perusahaan untuk ikut mengatasi permasalahan sosial dengan melakukan peningkatan ekonomi, perbaikan kualitas hidup masyarakat dan mengurangi berbagai dampak operasional pabrik perusahaan terhadap lingkungan sekitar.

\subsubsection{Prinsip Implementasi Corporate Social Responsibility}

Prinsip pengimplementasian CSR yang tertuang dalam ISO 26000:2010 (Laporan Tahunan PT Semen Tonasa, 2019:373-374) yakni sebagai berikut.

1) Principle of accountability (akuntabilitas), pelaksanaan program CSR dapat dipertanggungjawabkan sehingga terjauhkan dari potensi penyalahgunaan dan penyimpangan;

2) Principle of transparency (transparansi), keterbukaan dalam pengambilan keputusan dan keterbukaan mengemukakan informasi mengenai operasi bisnis dan pelaksanaan CSR;

3) Principle of ethical conduct (perilaku yang beretika), pelaksanaan program CSR harus mematuhi dan memenuhi etika perusahaan dan norma yang ada disekitar komunitas dimana bisnis perusahaan beroperasi; 
4) Principle of legal compliance (kepatuhan kepada hukum), memenuhi peraturan perundangundangan yang berlaku;

5) Principle of recognition of stakeholders and their concerns (menghormati pemangku kepentingan dan kepentingannya), memperhatikan aspirasi, minat dan kepedulian stakeholder dalam pelaksanaan CSR;

6) Principle respect of international norms and behavior (menghormati instrumen / badan-badan internasional), prinsip atas norma-norma, etika dan perilaku internasional yang sepatutnya ditaati dan dijadikan pedoman jika hukum dan norma lokal tidak memadai khususnya terkait isu-isu sosial-kemanusiaan, dan lingkungan hidup;

7) Principle of respect of human rights (menghormati dasar-dasar hak asasi manusia), prinsip mawas diri akan pelanggaran HAM, menghindari diri dari keterlibatannya, dan selalu proaktif mengkaji agar apakah ada aspek-aspek HAM yang cenderung bersentuhan dengan kebijakan dan operasi perusahaan.

\subsubsection{Metode Implementasi Corporate Social Responsibility}

Fahmi (2017:83) mengutarakan bahwa dengan perkembangan yang begitu pesat melahirkan dua metode dalam memperlakukan CSR, yaitu sebagai berikut.

1) Metode Cause Branding, adalah pendekatan Top Down, dalam hal ini perusahaan menentukan masalah sosial dan lingkungan seperti apa yang perlu dibenahi.

2) Metode Venture Philanthropy, yang merupakan pendekatan Botton Up, disini perusahaan membantu berbagai pihak non-profit dalam masyarakat sesuai apa yang dikehendaki masyarakat.

\subsubsection{Jenis-Jenis Program Implementasi Corporate Social Responsibility}

Kotler dan Lee dalam Azheri (2012:45-46) mengidentifikasikan bahwa ada enam pilihan program bagi perusahaan yang ingin melakukan inisiatif dan aktivitas berkaitan dengan berbagai masalah-masalah sosial sekaligus juga sebagai wujud komitmen dari CSRnya, beberapa diantaranya yakni sebagai berikut.

1) Cause promotion, adalah kegiatan yang dilakukan dalam bentuk memberikan kontribusi berupa dana dan penggalangan dana untuk meningkatkan kesadaran akan permasalahan-permasalahan sosial yang terjadi di masyarakat;

2) Cause-related marketing, adalah bentuk kontribusi perusahaan dengan menyisihkan beberapa persen dari pendapatannya yang diperoleh perusahaan sebagai donasi bagi permasalahan sosial tertentu, untuk periode tertentu atau produk tertentu;

3) Corporate social marketing, adalah upaya untuk membantu mengembangkan dan sekaligus mengimplementasikannya dalam bentuk kampanye dengan fokus mengubah perilaku negatif;

4) Corporate philanthropy, adalah inisiatif dari perusahaan dengan memberikan kontribusi langsung kepada suatu aktivitas amal, baik dalam bentuk donasi ataupun sumbangan tunai;

5) Community volunteering, adalah bentuk kegiatan yang dilakukan langsung oleh perusahaan dalam memberikan bantuan dan mendorong karyawan serta mitra bisnisnya untuk secara sukarela terlibat dan membantu masyarakat setempat;

6) Socially responsible business practices, adalah inisiatif perusahaan untuk mengadopsi dan melakukan praktik bisnis tertentu serta investasi yang ditujukan untuk meningkatkan kualitas sebuah komunitas dan melindungi lingkungan. 


\subsubsection{Peraturan Terkait Implementasi Corporate Social Responsibility}

Pemerintah telah menetapkan beberapa peraturan terkait dalam menjalankan CSR diantaranya adalah sebagai berikut.

1) Undang-Undang Nomor 40 tahun 2007 tentang Perseroan Terbatas

2) Pelaksanaan CSR di Indonesia diatur dalam UU Nomor 40 Tahun 2007 tentang Perseroan Terbatas dalam pasal 74.

3) Peraturan Pemerintah Nomor 47 Tahun 2012 tentang Tanggung Jawab Sosial dan Lingkungan Perseroan Terbatas

4) Peraturan Menteri Badan Usaha Milik Negara Republik Indonesia Nomor PER02/MBU/04/2020 tentang Perubahan Ketiga atas Peraturan Menteri Badan Usaha Milik Negara Republik Indonesia Nomor PER-09/MBU/2015 tentang Program Kemitraan dan Program Bina Lingkungan Badan Usaha Milik Negara.

\subsubsection{Indikator Implementasi Corporate Social Responsibility}

Menurut Post dalam Hadi (2011:61) menyatakan bahwa ragam tanggung jawab perusahaan terdiri dari tiga dimensi yang diuraikan sebagai berikut.

1) Economic Responsibility (Tanggung Jawab Ekonomi)

Keberadaan perusahaan ditujukan untuk meningkatkan nilai bagi shareholders, seperti: meningkatkan keuntungan, harga saham, dan pembayaran dividen. Bateman dan Scott A. Snell (2014:194) menyatakan bahwa "Tanggung jawab ekonomi (economic responsibilities) dari sebuah bisnis adalah memproduksi barang dan jasa yang dibutuhkan masyarakat pada harga yang menguntungkan perusahaan dan memenuhi kewajiban bagi para investor." Menurut Sigit (2012:85), program-program pendukung kegiatan CSR dalam hal ini seperti bantuan kepada masyarakat dalam bentuk kredit lunak, peralatan, dan pelatihan untuk pelaku UKM.

2) Legal Responsibility (Tanggung Jawab Hukum)

Sebagai bagian anggota masyarakat, perusahaan memiliki tanggung jawab mematuhi peraturan perundang-undangan yang berlaku. Mardikanto (2018:166) menyatakan bahwa salah satu prinsip yang harus mendasari pengimplementasian CSR yakni prinsip kepatuhan hukum, "Prinsip kepatuhan hukum berarti perusahaan harus memahami dan mematuhi semua peraturan, lokal, internasional, yang dinyatakan secara tertulis dan tidak tertulis, sesuai dengan prosedur tertentu." Bateman dan Scott A. Snell (2014:194) menyatakan bahwa "Tanggung jawab hukum adalah menaati hukum lokal, negara, federasi dan internasional yang relevan."

Beberapa program pendukung kegiatan CSR pada indikator ini seperti menjadi pembayar pajak yang baik, ikut terlibat dalam perumusan kebijakan publik untuk kepentingan bersama, serta mendukung dan melibatkan diri dalam program-program pemerintah yang berhubungan dengan kesehatan, olahraga, ketenagakerjaan, pendidikan, pengentasan kemiskinan, dan sebagainya (Sigit, 2012:86).

UU Nomor 32 tahun 2009 tentang Perlindungan Lingkungan dan Pengelolaan Lingkungan Hidup pasal 68 poin b dan c menyatakan bahwa "Setiap orang yang melakukan usaha dan/atau kegiatan berkewajiban untuk menjaga keberlanjutan fungsi lingkungan hidup dan menaati ketentuan tentang baku mutu lingkungan hidup dan/atau kriteria baku kerusakan lingkungan hidup."

3) Social Responsibility (Tanggung Jawab Sosial)

Social responsibility merupakan tanggung jawab perusahaan terhadap lingkungan dan para pemangku kepentingan (stakeholders). Menurut Sigit (2012:85), beberapa program program pendukung CSR sebagai berikut. Program pendukung pada fokus perhatian untuk masyarakat atau komunitas, seperti membangun infrastruktur dan layanan masyarakat, membuka dan memberikan 
lapangan pekerjaan bagi lingkungan sekitar, menyelenggarakan program perbaikan dan peningkatan kesehatan, serta memberikan beasiswa pendidikan kepada siswa dari keluarga miskin atau anak yang berbakat luar biasa. Selanjutnya program pendukung pada fokus perhatian untuk lingkungan seperti mendukung program pelestarian lingkungan dengan menjaga lingkungan dari pencemaran, melaksanakan penghijauan hutan dan penghijauan kota.

\subsection{Reputasi Perusahaan}

\subsubsection{Definisi Reputasi Perusahaan}

Reputasi perusahaan merupakan salah satu aset berharga perusahaan yang tidak berwujud, namun hanya bisa dirasakan dengan hasil penilaian baik atau buruk. Baiknya reputasi perusahaan tentu akan menguntungkan perusahaan, namun sebaliknya buruknya reputasi perusahaan akan merugikan perusahaan. "Sebuah organisasi akan menikmati reputasi yang baik pada saat performa atau kinerjanya secara konsisten memenuhi atau melampaui harapan dari para stakeholder" (Nova, 2011:309).

Dowling dalam Butterick (2013:58) mendefinisikan reputasi perusahaan sebagai "Hasil evaluasi (penilaian) yang menggambarkan citra perusahaan menurut masyarakat." Dilanjutkan oleh Ishaq (2017:165) bahwa "Penilaian ini membutuhkan waktu yang cukup panjang, bahkan bisa bertahun-tahun, karena penilaian didasarkan pada adanya konsistensi perkataan dan perbuatan." Butterick (2013:58) menyimpulkan bahwa "Reputasi perusahaan adalah 'representatif kolektif' serangkaian citra dan persepsi yang dihasilkan dari banyak pendapat yang berbeda tentang perusahaan." Jadi, penulis simpulkan bahwa reputasi perusahaan adalah hasil akumulasi penilaian yang menggambarkan citra dan persepsi masyarakat mengenai perusahaan dari waktu ke waktu.

\subsubsection{Indikator Reputasi Perusahaan}

Reputasi perusahaan yang baik merupakan hal yang senantiasa diharapkan oleh perusahaanperusahaan, maka dari itu diperlukan hal yang dapat membentuk dan mengembangkan reputasi perusahaan. Berdasarkan penelitian yang dilakukan oleh Shandwick dan Reputation Institute dalam Butterick (2013:62) terdapat enam elemen inti yang dapat membentuk bangunan reputasi perusahaan yaitu sebagai berikut.

\section{1) Tanggung Jawab}

Tanggung jawab berarti mendukung tujuan mulia, menunjukkan tanggung jawab lingkungan dan tanggung jawab sosial.

Seperti yang telah diuraikan sebelumnya bahwa tanggung jawab perusahaan tidak hanya berorientasi pada pemegang saham dengan mengoptimalkan aspek ekonomi atau mencari keuntungan, tetapi juga bertanggung jawab kepada masyarakat dalam rangka senantiasa meningkatkan kesejahteraan terkhususnya masyarakat sekitar perusahaan serta kepada pemerintah untuk kepatuhan hukum terhadap aturan yang berlaku dalam menjalankan usahanya.

Butterick (2013:65) juga menyatakan bahwa salah satu faktor yang dapat membantu perusahaan dalam membangun reputasi yang baik adalah relasi dengan warga masyarakat, dimana diuraikan bahwa suatu perusahaan yang sukses akan menjumpai masalah ketika tidak memberi perhatian pada warga masyarakat di lokasi perusahaan itu beroperasi. Hal ini disebabkan karena 'bad news' dapat menyebar dengan cepat, maka dari itu relasi yang baik menjadi suatu hal yang penting.

2) Komunikasi

Komunikasi ditandai dengan keterbukaan, pengungkapan secara penuh dan terbuka untuk berdialog. Terkait salah satu faktor yang menjadi dasar reputasi yakni komunikasi, Nova (2011:314-315) menyatakan bahwa "Komunikasi sangat penting untuk menyampaikan apa yang 
sebenarnya terjadi, sehingga terhindar dari opini di tengah masyarakat yang merugikan". Ross dalam Syahriani dan Mahmudi Siwi (2018:56) menyatakan bahwa "Komunikasi adalah suatu proses menyortir, memilih dan mengirimkan simbol - simbol sedemikian rupa sehingga membantu pendengar membangkitkan makna atau respons dari pikirannya yang serupa dengan yang dimaksudkan komunikator", sedangkan menurut Rogers dan D. Lawrence Kincaid dalam Syahriani dan Mahmudi Siwi (2018:56) mereka berpendapat bahwa "Komunikasi adalah suatu proses dimana dua orang atau lebih membentuk atau melakukan pertukaran informasi dengan satu sama lainnya, yang pada gilirannya akan tiba pada saling pengertian yang mendalam”.

3) Barang dan Jasa

Barang dan jasa berarti menawarkan kualitas dan inovasi yang berkelas tinggi, serta kepuasan pelanggan. Selanjutnya masih dalam Butterick (2013:65) menyatakan bahwa kualitas barang dan jasa merupakan hak yang benar-benar penting, apabila kualitas barang atau jasa yang dihasilkan tidak cukup baik, maka tidak ada satupun aktivitas PR yang dapat memoles reputasi perusahaan. Inovasi produk dalam Nova (2011:316-317) disebutkan sebagai salah satu faktor dasar reputasi karena dengan terus berinovasi menciptakan produk hal ini menunjukkan bahwa perusahaan ingin maju dalam bidangnya dan peduli dengan kebutuhan masyarakat.

4) Bakat

Bakat dapat diartikan bahwa memberikan hadiah kepada karyawan secara adil, keberagaman latar belakang karyawan dan menunjukkan kemampuan untuk menarik dan mempertahankan staf. 5) Matriks Keuangan

Matriks keuangan berarti melampaui para pesaing dan menunjukkan stabilitas keuangan serta nilai investasi jangka panjang.

6) Kepemimpinan

Kepemimpinan yang dibangun oleh CEO dan tim senior, menunjukkan kepemimpinan yang baik dan perilaku etis. Kepemimpinan perusahaan yang kuat, serta struktur dan kultur perusahaan juga menjadi salah satu dari faktor yang membantu perusahaan membangun reputasi yang baik (Butterick, 2013:65).

\subsection{Hubungan Implementasi Corporate Social Responsibility dan Reputasi Perusahaan}

Setiap perusahaan memiliki lingkungan eksternal, salah satunya adalah masyarakat sekitar perusahaan, maka dari itu pihak perusahaan harus menyadari pentingnya keberadaan lingkungan eksternal tersebut. Hal tersebut disebabkan karena setiap perusahaan tentu akan memberikan dampak positif dan negatif bagi masyarakat. Adanya dampak negatif yang dirasakan oleh masyarakat yang bermukim di sekitar perusahaan akan selaras dengan timbulnya kerugian dan pandangan negatif dari masyarakat tersebut, maka dari itu pihak perusahaan harus mencegah timbulnya kesan negatif agar tidak memicu konflik dengan masyarakat yang kemudian akan berdampak pada reputasi perusahaan itu sendiri.

Dampak negatif dari kegiatan operasional perusahaan tersebut dapat ditangani dengan cara bertanggung jawab kepada masyarakat melalui program CSR, dengan demikian selain dapat meminimalisir dampak negatif terhadap lingkungan juga dapat membuat perusahaan mendapatkan lisensi secara sosial untuk beroperasi dan memperbaiki hubungan dengan stakeholders, dengan mengimplementasikan CSR perusahaan juga dapat mempertahankan dan mendongkrak reputasi perusahaan (Suhandari dalam Fahmi, 2017:83).

Perusahaan yang sadar dan merespons lingkungan eksternalnya dengan melakukan hal-hal yang benar akan melihat reputasinya tumbuh dan berkembang, hal ini selaras dengan pernyataan Fombrun dalam Butterick (2013:62) yakni sebagai berikut. 
"Perusahaan-perusahaan yang dihargai dengan baik oleh masyarakat membangun reputasi mereka dengan mengembangkan praktik-praktik yang mengintegrasikan pertimbangan sosial dan ekonomi ke dalam strategi kompetitif mereka. Mereka tidak sekedar melakukan hal-hal secara baik, tetapi melakukan hal-hal dengan benar. Dalam melakukannya mereka berlaku sebagaimana warga Negara yang baik. Mereka mengawali kebijakan yang mencerminkan nilai-nilai inti yang mempertimbangkan kesejahteraan bersama dari para investor, pelanggan, dan karyawan yang mendorong lahirnya kepedulian terhadap pengembangan masyarakat lokal yang menjamin kualitas dan stabilitas lingkungan teknologi, barang serta jasa."

Yusdantara dan Gede Bayu Rahanatha (2015:815) mengungkapkan bahwa "Seiring dengan besarnya kontribusi perusahaan dalam program tanggung jawab sosial (CSR) akan mendongkrak reputasi perusahaan dimata konsumen dan masyarakat".

Itulah mengapa pengimplementasian CSR sangat berdampak pada reputasi sebuah perusahaan, namun perlu digaris bawahi pelaksanaan CSR yang dimaksud tidak hanya sekedar pelaksanaan tanpa perencanaan seperti tanpa adanya sosialisasi sebelumnya kepada masyarakat. Karena itu, Carter et al. dalam Margaretha dan Ratna Isnaini (2014:1) menyebutkan bahwa "Jika sebuah program CSR dilakukan dengan komunikasi yang baik kepada publik, maka program tersebut dapat membantu meningkatkan reputasi dan kredibilitas perusahaan."

\subsection{Penelitian Terdahulu}

Beberapa penelitian tentang pengaruh implementasi corporate social responsibility terhadap reputasi perusahaan yang telah dilakukan sebelumnya dapat dilihat sebagai berikut.

1) Ni Wayan Sugiarti (2015) melakukan penelitian terkait Pengaruh Persepsi tentang Corporate Social Responsibility terhadap Reputasi Perusahaan yang dimediasi oleh Citra Merek. Penelitian ini dilakukan di Kabupaten Gianyar. Sampel yang digunakan sebanyak 65 orang responden. Teknik analisis yang digunakan adalah path analysis dan uji sobel. Berdasarkan hasil analisis data diketahui terdapat pengaruh positif $C S R$ pada citra merek; terdapat pengaruh positif $C S R$ pada reputasi perusahaan; terdapat pengaruh antara citra merek pada reputasi perusahaan.

2) I Kadek Yusdantara dan Gede Bayu Rahanatha (2015) meneliti tentang Pengaruh Corporate Social Responsibility terhadap Reputasi Perusahaan yang dimediasi oleh Kepuasan Pelanggan (Studi pada PT Coca Cola Amatil Denpasar). Penelitian ini menggunakan riset kualitatif yaitu dengan menggunakan observasi dan kuesioner terhadap 120 konsumen dari produk PT Coca Cola Amatil di Kota Denpasar. Teknik analisis data yang digunakan adalah structural equation modeling (SEM). Diperoleh temuan bahwa CSR berpengaruh positif dan signifikan terhadap kepuasan pelanggan. CSR berpengaruh positif dan signifikan terhadap reputasi perusahaan. Kepuasan pelanggan berpengaruh positif dan signifikan terhadap reputasi perusahaan. Terakhir, kepuasan pelanggan sebagai variabel mediasi dalam pengaruh CSR terhadap reputasi perusahaan.

3) Farida Haerani (2017) meneliti tentang Strategi Corporate Social Responsibility (CSR) dalam Rangka Meningkatkan Reputasi Perusahaan (dalam Kajian Aspek Hukum Bisnis). Kegiatan aktivitas CSR di Indonesia cenderung lebih bersifat Philanthropy, yaitu usaha yang dilakukan perusahaan untuk memberikan dana kepada individu atau sekelompok masyarakat. Bentuk-bentuk lain dalam pelaksanaan CSR yang sifatnya justru mengembangkan pemangku kepentingan (kemitraan) demi kesejahteraan bersama. Aturan untuk pelaksanaan aktivitas CSR secara spesifik sampai saat ini belum ditetapkan oleh Pemerintah. Berbagai peraturan dan undang-undang yang mendukung CSR antara lain; Undang-Undang No.32 Tahun 2009 Tentang Perlindungan dan Pengelolaan Lingkungan Hidup, Undang-Undang Nomor 8 Tahun 
1999 tentang Perlindungan Konsumen merupakan aturan yang wajib dilakukan. Program CSR yang sifatnya filantropi sesuai kebutuhan masyarakat atau Stakeholders, misalnya pembangunan tempat ibadah, bantuan bencana alam. Metode partisipatif yaitu metode yang memastikan bahwa masyarakat terlibat secara aktif di dalam program CSR mulai dari pelaksanaan, pengawasan dan evaluasi. Metode ini diadopsi oleh PT Bank Mandiri (Persero) Tbk karena disesuaikan dengan program yang telah dirumuskan dan sasaran dari program tersebut. Seiring dengan perjalanan waktu, maka CSR akan menjadi semakin penting bagi perusahaan-perusahaan yang berada di Indonesia, khususnya bagi PT Bank Mandiri Tbk.

4) Theresia Diyah Wulandari (2011) meneliti tentang Pengaruh Tanggung Jawab Perusahaan dalam Menanggulangi Krisis terhadap Reputasi Perusahaan. Tujuan dalam penelitian ini adalah menemukan korelasi antara bentuk-bentuk tanggung jawab krisis perusahaan bagi pemulihan reputasi. Desain dari penelitian ini berasal teori komunikasi krisis situasional Coombs dan Holladay's yang menjadi panduan bagi manajer krisis memahami strategi respon krisis. Teori ini menyimpulkan bentuk-bentuk tanggung jawab krisis dan reputasi perusahaan merupakan variabel penentu. Analisa penelitian menggunakan metode survei responden yang berisi tiga stimulus kejadian krisis. Tujuan dari penelitian ini menyatakan bahwa pilihan tanggung jawab perusahaan memiliki pengaruh yang signifikan terhadap reputasi.

5) Farah Margaretha dan Ratna Isnaini (2014) meneliti tentang Board Diversity and Gender Composition on Corporate Social Responsibility and Firm Reputation in Indonesia. Tujuan dari penelitian adalah untuk mengetahui pengaruh keberagaman direksi dan komposisi direksi pada kinerja CSR dan reputasi perusahaan. Selain itu, penelitian ini juga mengungkapkan peran kinerja CSR sebagai mediator pada pengaruh antara keberagaman direksi, komposisi direksi dan reputasi perusahaan. Sampel diambil dari perusahaan penerima penghargaan Indonesia's Best Wealth Creator Award versi Majalah SWA Indonesia 2010-2012 dengan teknik purposive sampling. Hasil penelitian menunjukkan kinerja CSR dan gender berpengaruh positif terhadap reputasi perusahaan tetapi tidak berpengaruh terhadap keberagaman dewan direksi.

\subsection{Kerangka Konseptual}

Berdasarkan tinjauan pustaka dan penelitian terdahulu diketahui bahwa implementasi CSR berpengaruh positif terhadap reputasi perusahaan. Lebih jelasnya, gambar berikut dapat mendeskripsikan kerangka konseptual penelitian tentang "Pengaruh Implementasi Corporate Social Responsibility terhadap Reputasi Perusahaan pada PT Semen Tonasa”. 


\section{Gambar 1}

Kerangka Konseptual

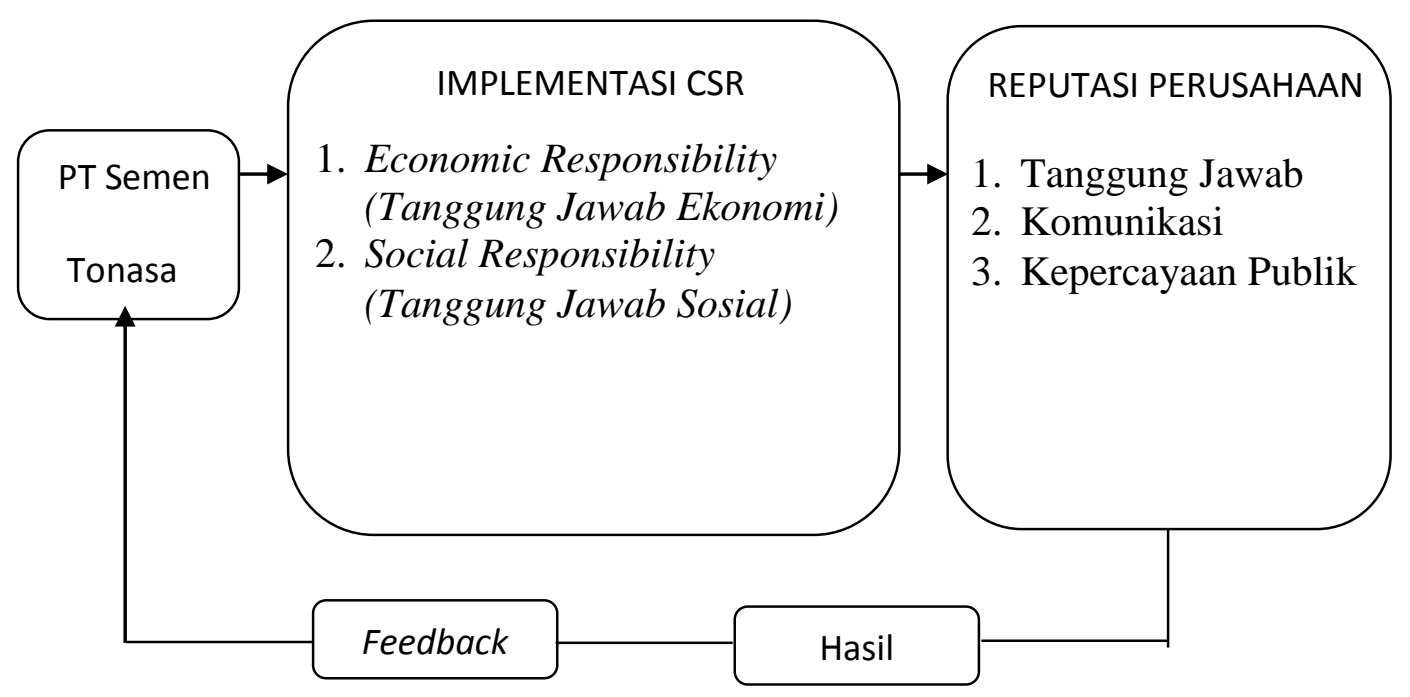

Berdasarkan latar belakang dan tinjauan pustaka yang ada, maka hipotesis pada penelitian ini adalah:

$\mathrm{H}_{0}$ : Implementasi corporate social responsibility tidak berpengaruh signifikan terhadap reputasi perusahaan pada PT Semen Tonasa;

$\mathrm{H}_{1}$ : Implementasi corporate social responsibility berpengaruh signifikan terhadap reputasi perusahaan pada PT Semen Tonasa.

\section{METODE PENELITIAN}

\subsection{Tipe Penelitian}

Tipe penelitian yang digunakan dalam penelitian ini adalah penelitian deskriptif dan asosiatif kausal. Jadi pada tipe penelitian ini, peneliti mencari bagaimana implementasi CSR dan bagaimana reputasi perusahaan, kemudian mencari besarnya pengaruh antara implementasi CSR dan reputasi perusahaan.

\subsection{Teknik Analisis Data}

Teknik analisis data yang digunakan dalam penelitian ini adalah data kuantitatif dengan pendekatan statistik yakni pendekatan pengukuran atau numerik terhadap pengumpulan maupun analisa data. Semua instrumen penelitian yang akan digunakan untuk melakukan pengukuran dengan tujuan menghasilkan data kuantitatif yang akurat harus mempunyai skala.

Skala pengukuran data dalam penelitian ini menggunakan skala likert yaitu skala yang digunakan untuk mengukur sikap, pendapat, dan persepsi seseorang atau sekelompok orang tentang fenomena sosial. Selanjutnya untuk mendapatkan hasil interpretasi, maka dalam mengukur skala likert digunakan rumus sebagai berikut.

Rumus:

$$
\text { Panjang Kelas Interval }=\frac{\text { Rentang Nilai }}{\text { Banyak Kelas Interval }}
$$


Dimana:

Rentang nilai $\quad=$ Nilai tertinggi - Nilai terendah

Banyak kelas interval $=5$

Berdasarkan rumus tersebut, maka panjang kelas interval adalah sebagai berikut.

$=\frac{5-1}{5}$

Panjang Kelas Interval $=\frac{\text { Rentang Nilai }}{\text { Banyak Kelas Interval }}$

$=0,8$

Berikut adalah interpretasi pengukuran skala likert yang digunakan.

Tabel 1

Range

\begin{tabular}{cccc}
\hline Nomor & Nilai Rata-Rata & Interpretasi & Konversi \\
\hline 1 & $1,00-1,80$ & Sangat Tidak Sesuai & Sangat Tidak Baik \\
2 & $1,81-2,60$ & Tidak Setuju & Tidak Baik \\
3 & $2,61-3,40$ & Kurang Sesuai & Kurang Baik \\
4 & $3,41-4,20$ & Sesuai & Baik \\
5 & $4,21-5,00$ & Sangat Sesuai & Sangat Baik \\
\hline
\end{tabular}

Sumber: Umar (2011)

Pengujian-pengujian yang digunakan dalam penelitian ini menggunakan alat bantu aplikasi IBM SPSS (International Business Machine Statistic Product and Service Solution) versi 24.

Adapun pengujian yang dilakukan yakni analisis deskriptif untuk menjelaskan masingmasing variabel dan analisis statistik inferensial yang terdiri dari uji instrumen, uji asumsi klasik, analisis regresi linear sederhana, analisis koefisien determinasi $\left(\mathrm{R}^{2}\right)$, dan Uji Hipotesis (Uji T).

3.3.1. Analisis Statistik Deskriptif

3.3.2. Analisis Statistik Inferensial

1) Uji Instrumen terdiri atas uji validitas dan reliabilitas. Pada dasarnya hasil penelitian yang valid dan reliabel adalah penelitian yang menggunakan instrumen yang valid dan reliabel, maka dari itu keduanya harus diuji.

2) Uji Asumsi Klasik digunakan untuk menguji apakah model regresi yang digunakan benarbenar mempunyai kesalahan asumsi seminimal mungkin sehingga model tersebut dapat digunakan untuk memprediksi suatu masalah. Adapun jenis uji asumsi klasik yang dilakukan sebagai berikut.

3) Analisis Regresi Linear Sederhana digunakan untuk mengukur besarnya pengaruh variabel implementasi CSR terhadap reputasi perusahaan. Bentuk umum persamaan regresi linear sederhana dirumuskan sebagai berikut (Sugiyono, 2017:273).

$$
\mathrm{Y}^{\prime}=\mathrm{a}+\mathrm{bX}+\mathrm{e}
$$

Dimana:

$\mathrm{Y}^{\prime}=$ Reputasi perusahaan

a $=$ konstanta atau bila harga $\mathrm{X}=0$

$\mathrm{b}=$ koefisien regresi (kemiringan)

$\mathrm{X}=$ Corporate social responsibility

4) Analisis Koefisien Determinasi $\left(\mathrm{R}^{2}\right)$ digunakan untuk mengukur proporsi pengaruh variabel implementasi CSR terhadap variabel reputasi perusahaan. Nilai koefisien determinasi $\left(\mathrm{R}^{2}\right)$ 
dapat diketahui dengan melihat nilai dari R. Square (Bahri, 2018:192). Hal ini berarti nilai ini menjadi dasar besaran persentase atau proporsi implementasi CSR terhadap reputasi perusahaan, dan nilai selebihnya berarti persentase atau proporsi variabel lain di luar penelitian ini.

5) Uji Hipotesis (Uji T) dilakukan untuk pengujian hipotesis variabel implementasi CSR terhadap reputasi perusahaan untuk menentukan kelayakan model regresi. Ketentuan yang digunakan dalam pengujian ini adalah $\mathrm{H}_{1}$ diterima dan $\mathrm{H}_{0}$ ditolak apabila nilai signifikansi kurang dari $(<)$ 0,05 (Bahri, 2018:193).

\subsection{Definisi Operasional}

3.3.1. Implementasi Corporate Social Responsibility adalah aktivitas tanggung jawab yang dilaksanakan PT Semen Tonasa untuk ikut mengatasi permasalahan sosial dengan melakukan peningkatan ekonomi, perbaikan kualitas hidup masyarakat dan mengurangi berbagai dampak operasional pabrik PT Semen Tonasa terhadap lingkungan sekitar.

Indikator yang digunakan dari implementasi CSR adalah sebagai berikut.

1) Economic Responsibility (tanggung jawab ekonomi), berarti PT Semen Tonasa yang menghasilkan keuntungan dari hasil pengelolaan perusahaan dalam rangka untuk meningkatkan nilai bagi masyarakat. Kegiatan pada indikator ini seperti memproduksi barang dan jasa yang dibutuhkan masyarakat, memberikan bantuan kredit lunak, peralatan dan pelatihan untuk pelaku UKM.

2) Social Responsibility (tanggung jawab sosial), merupakan tanggung jawab PT Semen Tonasa terhadap lingkungan dan masyarakat dengan cara memaksimalkan dampak positif pada masyarakat dan meminimalkan dampak negatif kegiatan operasional pabrik perusahaan. Adapun kegiatan pada indikator ini seperti menjaga lingkungan dari pencemaran, melaksanakan penghijauan, pembangunan prasarana dan fasilitas sosial, menyelenggarakan program perbaikan dan peningkatan kesehatan, serta memberikan beasiswa pendidikan.

3.3.2. Reputasi Perusahaan adalah hasil akumulasi penilaian yang menggambarkan citra dan persepsi masyarakat mengenai PT Semen Tonasa dari waktu ke waktu.

Indikator yang digunakan untuk mengukur reputasi perusahaan adalah sebagai berikut.

1) Tanggung jawab, merupakan PT Semen Tonasa yang melaksanakan tanggung jawab kepada seluruh pihak yakni pemegang saham, masyarakat, dan pemerintah. Aspek pengukuran dalam indikator ini seperti perusahaan selalu mengoptimalkan aspek ekonomi atau mencari keuntungan, bertanggung jawab kepada masyarakat dalam rangka meningkatkan kesejahteraan masyarakat sekitar, dan bertanggung jawab kepada pemerintah untuk kepatuhan hukum terhadap aturan yang berlaku dalam menjalankan usahanya.

2) Komunikasi, merupakan proses pengiriman dan/atau pertukaran informasi antar pihak PT Semen Tonasa dengan masyarakat dalam rangka terciptanya kesepemahaman. Adapun aspek pengukuran pada indikator ini seperti selalu menjalin komunikasi, memberikan informasi yang jelas, dan terbuka untuk berdialog.

3) Kepercayaan publik, merupakan keyakinan masyarakat kepada pihak PT Semen Tonasa. Hal yang diukur dalam indikator ini seperti pengalaman, pencapaian atau realisasi janji-janji yang telah ditetapkan, keselarasan antara ucapan dan tindakan perusahaan, keputusan yang diambil dan keberlanjutan terhadap suatu entitas tertentu. 


\subsection{Uji Validitas}

Uji validitas berguna untuk mengetahui valid atau tidaknya item-item pertanyaan pada kuesioner. Item pertanyaan dinyatakan valid jika nilai signifikansinya kurang dari $(<) 0,05$. Adapun hasil pengujian validitas terhadap variabel implementasi CSR dan reputasi perusahaan yaitu sebagai berikut.

\section{Tabel 2}

Hasil Uji Validitas

\begin{tabular}{lcccc}
\hline \multicolumn{1}{c}{ Indikator } & Item & R Hitung & $\begin{array}{c}\text { Nilai } \\
\text { Signifikansi }\end{array}$ & Kesimpulan \\
\hline & Variabel Implementasi CSR (X) & & \\
\hline \multirow{2}{*}{$\begin{array}{l}\text { Economic Responsibility (Tanggung } \\
\text { Jawab Ekonomi) }\end{array}$} & $\mathrm{X}_{1.1}$ & 0.556 & 0,000 & Valid \\
& $\mathrm{X}_{1.2}$ & 0.590 & 0,000 & Valid \\
& $\mathrm{X}_{1.3}$ & 0.728 & 0,000 & Valid \\
Social Responsibility (Tanggung & $\mathrm{X}_{2.1}$ & 0.770 & 0,000 & Valid \\
Jawab Sosial) & $\mathrm{X}_{2.2}$ & 0.650 & 0,000 & Valid \\
& $\mathrm{X}_{2.3}$ & 0.674 & 0,000 & Valid \\
& $\mathrm{X}_{2.4}$ & 0.783 & 0,000 & Valid \\
& $\mathrm{X}_{2.5}$ & 0.719 & 0,000 & Valid \\
\hline \multirow{3}{*}{ Komunikasi } & Variabel Reputasi Perusahaan & & Valid \\
& $\mathrm{Y}_{1.1}$ & 0.368 & 0,000 & Valid \\
& $\mathrm{Y}_{1.2}$ & 0.809 & 0,000 & Valid \\
Tanggung Jawab & $\mathrm{Y}_{1.3}$ & 0.713 & 0,000 & Valid \\
& $\mathrm{Y}_{2.1}$ & 0.803 & 0,000 & Valid \\
& $\mathrm{Y}_{2.2}$ & 0.811 & 0,000 & Valid \\
Kepercayaan Publik & $\mathrm{Y}_{2.3}$ & 0.697 & 0,000 & Valid \\
& $\mathrm{Y}_{3.1}$ & 0.528 & 0,000 & Valid \\
& $\mathrm{Y}_{3.2}$ & 0.779 & 0,000 & Valid \\
\hline
\end{tabular}

Sumber: SPSS diolah, 2020

Tabel 2 menunjukkan hasil bahwa seluruh item pertanyaan memiliki nilai signifikansi kurang dari (<) syarat nilai signifikansi 0,05 sehingga hal ini berarti semua item pertanyaan pada kuesioner dinyatakan valid.

\subsection{Uji Reliabilitas}

Uji reliabilitas berfungsi untuk mengetahui tingkat konsistensi kuesioner sehingga dapat diandalkan walaupun penelitian dilakukan berulang kali dengan kuesioner yang sama. Dasar pengambilan keputusan dalam menentukan apakah kuesioner reliabel atau tidak pada penelitian ini yakni dengan melihat nilai koefisien cronbach alpha. Jika nilai hasil menunjukkan lebih besar dari (>) syarat nilai cronbach alpha sebesar 0.60, maka kuesioner dinyatakan reliabel.Berikut hasil uji reliabilitas terhadap variabel implementasi CSR dan reputasi perusahaan yang diperoleh yakni sebagai berikut. 
Tabel 3

Hasil Uji Reliabilitas

\begin{tabular}{lcc}
\hline \multicolumn{1}{c}{ Variabel } & Nilai Cronbach Alpha & Kesimpulan \\
\hline Implementasi CSR & 0,837 & Reliabel \\
Reputasi Perusahaan & 0,877 & Reliabel \\
\hline
\end{tabular}

Sumber: SPSS diolah, 2020

Tabel 3 menunjukkan hasil bahwa kedua indikator variabel baik variabel implementasi CSR maupun variabel reputasi perusahaan memiliki nilai koefisien cronbach alpha lebih besar dari (>) syarat nilai cronbach alpha 0,60 . Hal ini berarti kuesioner dinyatakan reliabel.

\section{HASIL DAN PEMBAHASAN}

4.1 HASIL

4.1.1 Uji Autokorelasi

Berdasarkan hasil pengujian, diperoleh nilai durbin waston sebesar 1,848. Hal tersebut berarti nilai durbin waston berada pada kategori pertama, yakni di antara -2 sampai +2 . Sehingga dapat disimpulkan bahwa tidak terjadi autokorelasi pada model regresi penelitian ini.

4.1.2 Uji Heteroskedastisitas

Berdasarkan hasil analisis regresi linear sederhana, diketahui bahwa nilai konstanta (a) sebesar 7.048 dan nilai koefisien regresi (b) sebesar 0.904, sehingga menghasilkan persamaan regresi sebagai berikut.

$$
\mathrm{Y}^{\prime}=7.048+0.904 \mathrm{X}+\mathrm{e}
$$

Persamaan tersebut dapat diterjemahkan sebagai berikut.

1) Konstanta (a) sebesar 7.048 mengandung arti bahwa jika nilai variabel implementasi CSR adalah 0, maka nilai konsisten variabel reputasi perusahaan adalah sebesar 7.048;

2) Koefisien regresi (b) variabel implementasi CSR sebesar 0.904 berarti bahwa setiap penambahan 1 satuan skor variabel implementasi CSR, maka nilai variabel reputasi perusahaan bertambah sebesar 0.904 atau dapat dinyatakan bahwa semakin meningkat implementasi CSR maka semakin meningkat pula reputasi perusahaan. Sehingga dapat dikatakan bahwa arah pengaruh variabel implementasi CSR terhadap variabel reputasi perusahaan adalah positif.

\subsubsection{Analisis Koefisien Determinasi $\left(\mathrm{R}^{2}\right)$}

Hasil dari analisis memperlihatkan nilai koefisien determinasi yang ditunjukkan dengan nilai $R$ Square adalah sebesar 0,663. Maka dapat disimpulkan bahwa variabel implementasi CSR memiliki proporsi sebesar $66,3 \%$ terhadap variabel reputasi perusahaan, sedangkan sisanya yaitu sebesar 33,7\% dipengaruhi oleh variabel lain diluar penelitian ini.

4.1.4 Uji Hipotesis (Uji T)

Hasil pengujian hipotesis diperoleh nilai signifikansi sebesar 0,000 kurang dari $(<) 0,05$, sehingga $\mathrm{H}_{1}$ diterima dan $\mathrm{H}_{0}$ ditolak. Hal ini kemudian dapat diartikan bahwa implementasi corporate social responsibility berpengaruh signifikan terhadap reputasi perusahaan pada PT Semen Tonasa.

\subsection{Pembahasan}

4.2.1 Implementasi Corporate Social Responsibility pada PT Semen Tonasa

Implementasi CSR yang baik tidak terlepas dari perencanaan yang baik pula. Karena itu, PT

Semen Tonasa telah merancang blueprint sebagai pedoman dan acuan pelaksanaan program CSR yang berbasis ISO 26000. Hal ini tentu dilakukan agar perencanaan hingga evaluasi dari 
pengimplementasian program CSR dapat dipastikan berjalan dengan efektif untuk mencapai tujuan yang diinginkan.

Sasaran atau target pengimplementasian CSR yakni stakeholder khususnya masyarakat dan lingkungan sekitar yang sudah seharusnya mendapatkan perhatian lebih dari pihak perusahaan. Masyarakat atau daerah dalam pandangan PT Semen Tonasa terbagi atas tiga bagian berdasarkan besarnya dampak yang dirasakan masyarakat akibat kegiatan operasional perusahaan, yakni Ring 1, Ring 2, dan Ring 3.

Daerah yang terkena dampak langsung dari kegiatan operasional PT Semen Tonasa, baik aktivitas pabrik, pelabuhan, BTG (Boiler Turbin Generator), maupun penambangan perusahaan, dengan jarak maksimum $5 \mathrm{~km}$ disebut sebagai Ring 1. Daerah yang tidak terkena dampak langsung dari kegiatan operasional PT Semen Tonasa, namun wilayahnya sering menjadi jalur yang dilewati kendaraan produksi/pemasaran perusahaan di Kabupaten Pangkep disebut sebagai Ring 2. Sedangkan daerah yang tidak terkena dampak langsung dari proses produksi perusahaan, tidak terkena rencana perluasan pabrik atau tambang tapi sering menjadi jalur distribusi perseroan disebut dengan Ring 3 (Laporan Tahunan PT Semen Tonasa, 2019:387). Secara rinci, pembagian tersebut seperti yang terlihat pada gambar berikut.

\section{Gambar 2}

\section{Daerah Penyaluran CSR}

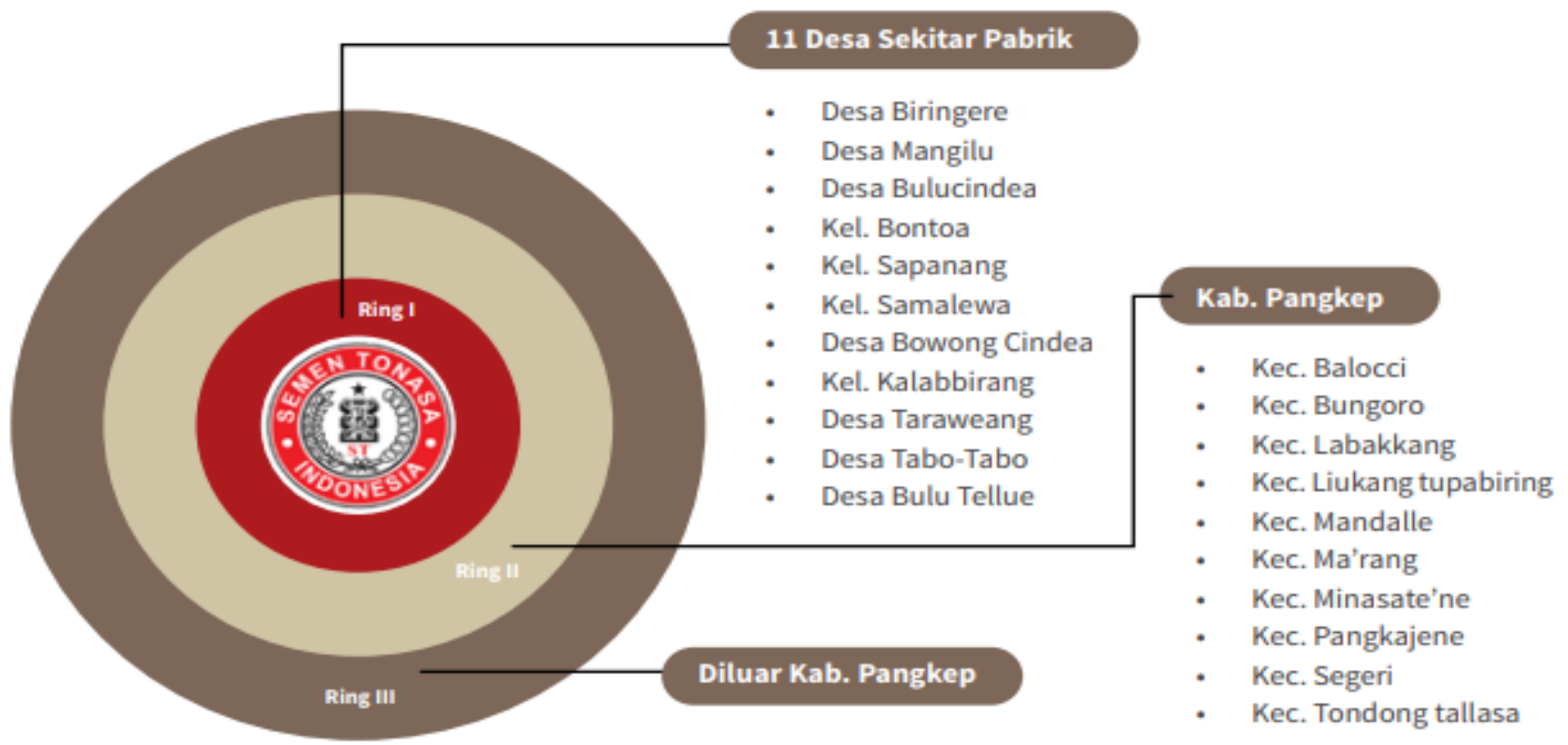

Sumber: Laporan Tahunan PT Semen Tonasa, 2019

Gambar 2 memperlihatkan bahwa Ring 1 terdiri dari 11 Desa/Kelurahan. Desa Biring Ere termasuk daerah Ring 1 bahkan daerah tersebut merupakan desa dimana pabrik PT Semen Tonasa dan kantor pusat beroperasi. Pelaksanaan CSR di Desa Biring Ere, perusahaan bekerja sama dengan forum Mitra Amanah dan pihak kantor Desa, serta dinas terkait lainnya. Program CSR diwujudkan ke dalam beberapa jenis program yang dikenal dengan Program Tonasa Bersaudara dengan lima pilar sebagai program unggulan, yaitu sebagai berikut. 
Tonasa Mandiri merupakan program CSR untuk membangun kemandirian dan pemberdayaan ekonomi masyarakat, mendorong pengembangan usaha kecil menengah (UKM), dan pengentasan kemiskinan. Tonasa Cerdas merupakan program CSR untuk meningkatkan kualitas pendidikan dan keterampilan masyarakat. Tonasa Sehat merupakan program yang bertujuan untuk meningkatkan kesehatan masyarakat sekitar. Tonasa Bersahaja merupakan program yang difokuskan untuk pengembangan tata nilai dan norma yang ada di masyarakat. Tonasa Hijau merupakan program yang ditujukan untuk pemenuhan kebutuhan dasar prasarana dan sarana lingkungan permukiman serta kegiatan penghijauan (Laporan Tahunan PT Semen Tonasa, 2019: 382-384).

Adapun realisasi pelaksanaan kegiatan CSR PT Semen Tonasa di Desa Biring Ere pada tahun 2019 dapat dilihat sebagai berikut.

\section{Tabel 4}

Realisasi Kegiatan CSR PT Semen Tonasa Tahun 2019

\begin{tabular}{|c|c|c|}
\hline NO. & Kegiatan & Lokasi \\
\hline A. & Tonasa Mandiri & \\
\hline 1. & Penguatan forum & Desa Biring Ere \\
\hline 2. & Pengembangan kelompok usaha servis elektronik & Kampung Balang \\
\hline 3. & $\begin{array}{l}\text { Bantuan peralatan usaha kue tradisional dan makanan } \\
\text { siap saji }\end{array}$ & Kampung Balang \\
\hline 4. & Pelatihan dan pengadaan alat fotografer & Dusun Borong Untia \\
\hline 5. & Pengembangan kapasitas produksi usaha paving block & Kampung Palattae \\
\hline 6. & Bantuan peralatan usaha salon & Dusun Biring Ere \\
\hline 7. & Pinjaman modal untuk UKM & Pangkep \\
\hline B. & Tonasa Sehat & \\
\hline 8. & Pengadaan kendaraan pengangkut sampah & Desa Biring Ere \\
\hline 9. & Pengobatan Gratis & Ring 1 \\
\hline 10. & Donor Darah & Kantor Pusat \\
\hline C. & Tonasa Bersahaja & \\
\hline 11. & $\begin{array}{l}\text { Pembinaan keseniaan tradisional melalui pelatihan, } \\
\text { ketersediaan peralatan dan promosi }\end{array}$ & Dusun Borong Untia \\
\hline 12. & Pembagian sapi qurban & Ring 1 \\
\hline 13. & $\begin{array}{l}\text { Buka puasa, pemberian donasi dan bingkisan kepada } \\
\text { janda, manula, dan SLB }\end{array}$ & Ring 1 \\
\hline 14. & Pasar murah & Ring 1 \\
\hline 15 . & Liga sepak bola & Ring 1 \\
\hline D. & Tonasa Hijau & \\
\hline 16. & Bedah rumah & Kampung Palattae \\
\hline 17. & Penghijauan di sekolah dan kantor desa & $\begin{array}{l}\text { Dusung Borong Untia dan } \\
\text { Biring Ere }\end{array}$ \\
\hline E. & Tonasa Cerdas & \\
\hline 18. & $\begin{array}{l}\text { Lomba sains tingkat SD, SMP, dan SMA se-kabupaten } \\
\text { Pangkep }\end{array}$ & Pangkep \\
\hline 19. & Beasiswa untuk mahasiswa & Ring 1 \\
\hline 20. & Hibah buku untuk sekolah & Pangkep \\
\hline 21. & Bimbingan belajar & Ring 1 \\
\hline
\end{tabular}

Sumber: Data PT Semen Tonasa Tahun 2019 diolah 
Tabel 4 merupakan hasil penggabungan data yang diperoleh dari Forum Mitra Amanah dan dari website resmi PT Semen Tonasa. Data tersebut merupakan program-program CSR PT Semen Tonasa yang telah dilaksanakan pada tahun 2019 di Desa Biring Ere dan daerah Ring 1 serta Kabupaten Pangkajene dan Kepulauan secara keseluruhan yang Desa Biring Ere juga termasuk di dalamnya.

Adanya Forum Mitra Amanah berarti bahwa PT Semen Tonasa dalam pengimplementasian CSR menggabungkan dua metode seperti teori yang diutarakan oleh Fahmi (2017:83) yakni metode venture philanthropy dengan pendekatan botton up dan metode cause branding dengan pendekatan top down. Berdasarkan metode pertama, PT Semen Tonasa menerima saran dan melaksanakan kegiatan CSR yang dibutuhkan masyarakat melalui forum tersebut, selain itu PT Semen Tonasa juga menerapkan metode kedua yakni melakukan tindakan inisiatif dalam melaksanakan kegiatan CSR yang lainnya.

Data pada Tabel 4 juga menunjukkan bahwa PT Semen Tonasa telah melaksanakan kelima program CSR Tonasa Bersaudara yang menyelaraskan pelaksanaan program kemandirian perekonomian masyarakat, peningkatan kualitas pendidikan dan kesehatan masyarakat, memperhatikan kondisi sosial dalam hal seni, budaya, dan olahraga, serta pelestarian alam. Konsep tersebut juga selaras dengan definisi CSR yang diutarakan oleh Fajar (2010:34) yakni sebagai aktivitas peningkatan ekonomi, perbaikan kualitas hidup masyarakat dan mengurangi berbagai dampak operasionalnya terhadap lingkungan.

Selanjutnya, hasil analisa dari tanggapan responden mengenai pertanyaan-pertanyaan pada indikator economic responsibility (tanggung jawab ekonomi) yang mencakup $\mathrm{X}_{1.1}$ perusahaan merupakan produsen semen dan penyedia jasa pembangunan berada pada kategori sangat baik, $\mathrm{X}_{1.2}$ pemberian bantuan kredit kepada pelaku UKM berada pada kategori sangat baik serta $\mathrm{X}_{1.3}$ selalu memberi bantuan pelatihan untuk pelaku UKM jika diinterpretasikan berada pada kategori baik.

Selanjutnya terkait pertanyaan-pertanyaan pada indikator social responsibility (tanggung jawab sosial) yang mencakup $\mathrm{X}_{2.1}$ penjagaan lingkungan terhadap pencemaran, $\mathrm{X}_{2.2}$ penghijauan, $\mathrm{X}_{2.3}$ pembangunan prasarana dan fasilitas umum, $\mathrm{X}_{2.4}$ perbaikan dan peningkatan kesehatan bagi masyarakat, serta $\mathrm{X}_{2.5}$ pemberian beasiswa pendidikan jika diinterpretasikan nilai masing-masing item berada pada kategori baik.

Hasil dari nilai masing-masing indikator, diketahui bahwa indikator economic responsibility (tanggung jawab ekonomi) bernilai rata-rata tertinggi dan social responsibility (tanggung jawab sosial) bernilai rata-rata terendah. Jika dilihat dari nilai masing-masing item, diketahui bahwa item $\mathrm{X}_{1.1}$ mempunyai nilai tertinggi dari kedelapan item pada kedua indikator variabel implementasi CSR tersebut, hal ini dikarenakan masyarakat telah sangat mengenal keunggulan dan kebersaingan harga dari produk yang disiapkan oleh PT Semen Tonasa untuk memenuhi kebutuhan masyarakat dalam hal bahan bangunan. Meskipun demikian, item $\mathrm{X}_{2.1}$ berada pada nilai terendah dibandingkan dengan nilai item yang lain. Hal ini dikarenakan dampak negatif terbesar yang dirasakan oleh masyarakat terkait keberadaan perusahaan yakni adanya pencemaran udara dari debu karena kegiatan operasional pabrik perusahaan dan lalu lalang truk pengangkut material yang hanya bisa diminimalisir namun tidak dapat dihilangkan sehingga meresahkan masyarakat yang bermukim di sekitar pabrik.

Adapun tertulis nilai rata-rata kedua indikator implementasi CSR serta variabel implementasi CSR secara keseluruhan jika diinterpretasikan maka masing-masing berada pada kategori baik. Hal ini berarti persepsi masyarakat terhadap implementasi CSR pada PT Semen Tonasa adalah baik.

Sementara jika diuraikan berdasarkan kelima pilar program Tonasa Bersaudara, implementasi kegiatan CSR yang dilaksanakan pada tahun 2019 di Desa Biring Ere pada pilar 
Tonasa Mandiri telah dilaksanakan beberapa kegiatan pengembangan usaha UKM, hanya saja program tersebut belum bisa didapatkan oleh semua pelaku UKM di Desa Biring Ere karena adanya pembagian kuota penyaluran dana untuk masing-masing daerah.

Pada pilar Tonasa Sehat, kegiatan rutin yang dilaksanakan pertiga bulan yakni donor darah, adapun pengadaan sarana umum pada tahun lalu yakni pengadaan kendaraan pengangkut sampah yang disesuaikan dengan kebutuhan mendesak masyakarakat pada waktu tersebut serta pengobatan gratis juga merupakan kegiatan rutin setiap tahunnya yang pelaksanaanya bekerja sama dengan puskesmas setempat dan dokter Tonasa.

Selanjutnya pada pilar Tonasa Bersahaja, peningkatan kesenian hanya dilakukan di salah satu dusun sehingga tidak merata, kegiatan olahraga juga dilaksanakan sekali dalam kurun waktu setahun, pembagian sembako dan pelaksanaan pasar murah juga dilaksanakan untuk membantu meringankan biaya kehidupan sehari-hari masyarakat.

Kegiatan yang dilaksanakan pada pilar Tonasa Hijau yakni bedah rumah salah satu masyarakat miskin di kampung Palattae yang dipilih berdasarkan hasil survey dan bekerja sama dengan pemerintah setempat serta kegiatan penghijauan untuk Desa Biring Ere hanya dilaksanakan di sekitar sekolah Tonasa dan kantor desa.

Terakhir, kegiatan yang telah dilaksanakan pada pilar Tonasa Cerdas yakni perlombaan science, penghibahan buku, bimbingan belajar, dan beasiswa untuk mahasiswa ring 1 yang melanjutkan kuliah di PNUP dengan kriteria tertentu, serta penggratisan sekolah bagi SD dan SMP Tonasa, meskipun untuk PAUD, TK, dan SMA belum digratiskan sepenuhnya.

Data tambahan diperoleh dari Ibu Samsiah, salah satu masyarakat Desa Biring Ere pada saat wawancara yang menuturkan bahwa selain sebagai penyerap tenaga kerja dan telah memberikan andil dengan memberikan bantuan-bantuan dalam rangka meningkatkan kesejahteraan masyarakat sekitar pabrik, seperti listrik dan pembangunan rumah masyarakat, keberadaan pabrik PT Semen Tonasa juga berdampak negatif bagi masyarakat dan lingkungan sekitar karena polusi udara akibat debu pabrik terlebih pada musim kemarau.

Meskipun demikian, beliau juga menyatakan bahwa PT Semen Tonasa telah mematuhi aturan hukum seperti pengelolaan lingkungan seitaran pabrik, namun masih perlu ditingkatkan lagi. Lebih lanjut, beliau menyatakan bahwa pelaksanaan program CSR PT Semen Tonasa telah baik dan telah memenuhi harapannya sebagai masyarakat, meskipun pada dasarnya masyarakat terkadang merasa belum cukup karena adanya kebutuhan yang terus meningkat.

\subsubsection{Reputasi Perusahaan pada PT Semen Tonasa}

Reputasi perusahaan merupakan aset berharga perusahaan. Baiknya reputasi perusahaan dimata masyarakat akan menguntungkan perusahaan, namun sebaliknya buruknya reputasi perusahaan akan merugikan perusahaan.

Seperti yang telah dipaparkan sebelumnya, keberadaan pabrik PT Semen Tonasa memberikan dampak negatif yang sangat dirasakan oleh masyarakat sekitar. Dampak tersebut tentu dapat menimbulkan pandangan negatif dari masyarakat yang akan berujung pada reputasi perusahaan yang menurun. Sudah seharusnya pihak PT Semen Tonasa telah melakukan tindakan antisipasi atau peminimalisiran atas kondisi tersebut. Karena itu, salah satu langkah yang telah ditempuh oleh PT Semen Tonasa yakni mengoptimalkan pengimplementasian CSR.

Hasil analisa dari tanggapan responden mengenai item-item pertanyaan pada indikator tanggung jawab yang mencakup $\mathrm{Y}_{1.1}$ tentang PT Semen Tonasa merupakan perusahaan besar, berada pada kategori sangat baik. Item $\mathrm{Y}_{1.2}$ terkait pelaksanaan tanggung jawab sosial dan lingkungan dengan baik, dan item $\mathrm{Y}_{1.3}$ terkait senantiasa menaati aturan yang berlaku masingmasing berada pada kategori baik. 
Analisa terhadap tanggapan untuk pertanyaan-pertanyaan pada indikator komunikasi yang mencakup $\mathrm{Y}_{2.1}$ tentang perusahaan yang selalu menjalin komunikasi dengan masyarakat, $\mathrm{Y}_{2.2}$ memberikan informasi yang jelas, dan $\mathrm{Y}_{2.3}$ selalu menerima masyarakat yang akan berdialog ditemukan bahwa nilai rata-rata untuk masing-masing pertanyaan dapat diinterpretasikan ke dalam kategori baik.

Analisa selanjutnya yakni terhadap ketiga item pertanyaan indikator kepercayaan publik yang terdiri atas item $\mathrm{Y}_{3.1}$ mengenai PT Semen Tonasa merupakan perusahaan yang berpengalaman di bidangnya berada pada kategori sangat baik, sedangkan item $\mathrm{Y}_{3.2}$ selalu memenuhi janji-janjinya kepada masyarakat, dan item $\mathrm{Y}_{3.3}$ selalu mengambil keputusan yang bersifat jangka panjang untuk kepentingan masyarakat berada pada kategori baik.

Adapun diketahui bahwa nilai rata-rata indikator tanggung jawab jika diinterpretasikan berada pada kategori sangat baik, sedangkan indikator komunikasi, dan kepercayaan publik serta variabel reputasi perusahaan secara keseluruhan jika diinterpretasikan maka masing-masing berada pada kategori baik. Maka dapat disimpulkan bahwa persepsi masyarakat terhadap reputasi perusahaan PT Semen Tonasa adalah baik.

Hasil dari nilai masing-masing indikator, diketahui bahwa indikator tanggung jawab bernilai rata-rata tertinggi dan indikator komunikasi bernilai rata-rata terendah. Jika dilihat dari nilai kesembilan item pada ketiga indikator variabel reputasi perusahaan, diketahui bahwa nilai item $\mathrm{Y}_{1.1}$ berada pada nilai tertinggi. Hal ini dikarenakan PT Semen Tonasa merupakan salah satu bagian dari group Semen Indonesia dan juga merupakan perusahaan persemenan terbesar di Indonesia Timur. Nilai $\mathrm{Y}_{3.2}$ berada pada nilai terendah, karena masih adanya tuntutan-tuntutan masyarakat yang belum sepenuhnya direalisasikan oleh perusahaan dan perbedaan tingkat kebutuhan setiap masyarakat dengan jenis program CSR yang telah dilaksanakan perusahaan belum sepenuhnya seperti apa yang diinginkan semua lapisan masyakarat, sehingga masyarakat belum sepenuhnya menganggap PT Semen Tonasa selalu memenuhi janji-janjinya.

\subsubsection{Pengaruh Implementasi Corporate Social Responsibility terhadap Reputasi Perusahaan pada} PT Semen Tonasa

Tidak dapat dipungkiri bahwa adanya dampak negatif yang dirasakan masyarakat dan lingkungan sekitar pabrik merupakan akibat dari kegiatan operasional pabrik perusahaan. Hal tersebut dikuatkan atas penuturan sebagian besar masyarakat ketika mengisi kuesioner, mereka sangat mengeluhkan polusi udara yang disebabkan oleh debu dari pabrik, tetapi disisi lain adanya bantuan-bantuan ataupun pengimplementasian program CSR yang mereka rasakan manfaatnya membuat reputasi perusahaan PT Semen Tonasa baik dalam persepsi masyarakat Desa Biring Ere.

Perusahaan pada umumnya telah menjadikan CSR sebagai bagian dari biaya strategi bisnis perusahaan yang akan memberikan input baik bagi perusahaan itu sendiri. Hal tersebut seperti apa yang diutarakan oleh Sugiarti (2015:2574) bahwa "CSR akan menjadi strategi bisnis yang inheren dalam perusahaan untuk menjaga atau meningkatkan daya saing melalui reputasi perusahaan”. Karena itu, selain sebagai perwujudan kesadaran dan kewajiban perusahaan, pelaksanaan program CSR juga akan sejalan dengan pengharapan perusahaan atas beberapa manfaat dari pengimplementasian CSR tersebut.

Besarnya kontribusi perusahaan dalam pengimplementasian CSR akan selaras dengan peningkatan reputasi perusahaan di mata masyarakat (Yusdantara dan Gede Bayu Rahanatha, 2015:815). Hal ini dibuktikan dengan persamaan model regresi yang diperoleh pada penelitian ini yakni $Y^{\prime}=7.048+0.904 \mathrm{X}+\mathrm{e}$ dan hasil uji t yang menunjukkan taraf signifikansi sebesar 0,000 $<0,05$. Adapun besaran pengaruh yang diperoleh dari hasil uji koefisien determinasi sebesar 0,663 yang berarti proporsi implementasi CSR terhadap reputasi perusahaan sebesar $66,3 \%$ yang dapat 
dikategorikan sebagai besaran proporsi sedang atau baik, sedangkan 33,7\% lainnya dipengaruhi oleh faktor lain. Ketiga hasil pengujian tersebut membuktikan bahwa implementasi CSR berpengaruh signifikan dan positif terhadap reputasi perusahaan pada PT Semen Tonasa. Sehingga disimpulkan bahwa jika dilakukan perbaikan ataupun peningkatan pada implementasi CSR, maka reputasi perusahaan juga akan mengalami peningkatan yang selaras.

Adanya harapan masyarakat kepada PT Semen Tonasa khususnya terkait pengimplementasian program CSR yang telah dipenuhi oleh pihak PT Semen Tonasa dengan baik membuat masyarakat juga memberikan umpan balik yang baik dalam hal ini penilaian positif kepada PT Semen Tonasa.

Hasil penelitian ini sejalan dengan penelitian Sugiarti (2015) yang menemukan bahwa terdapat pengaruh positif CSR pada reputasi. Margaretha dan Ratna Isnaini (2014) mengemukakan bahwa kinerja CSR berpengaruh positif terhadap reputasi perusahaan. Yusdantara dan Gede Bayu Rahanatha (2015) menyimpulkan bahwa CSR berpengaruh positif dan signifikan terhadap reputasi perusahaan.

\section{SIMPULAN}

Berdasarkan hasil dan pembahasan dari penelitian yang dilakukan tentang pengaruh implementasi corporate social responsibility terhadap reputasi perusahaan pada PT Semen Tonasa, maka peneliti dapat menarik beberapa kesimpulan sebagai berikut.

1. Persepsi masyarakat terhadap implementasi corporate social responsibility pada PT Semen Tonasa adalah baik dengan indikator tertinggi yakni economic responsibility (tanggung jawab ekonomi) sedangkan indikator terendah yakni social responsibility (tanggung jawab sosial).

2. Persepsi masyarakat terhadap reputasi perusahaan pada PT Semen Tonasa adalah baik dengan indikator tertinggi yakni tanggung jawab sedangkan indikator terendah yakni komunikasi.

Berdasarkan hasil penelitian, dinyatakan bahwa implementasi corporate social responsibility berpengaruh signifikan dan positif terhadap reputasi perusahaan pada PT Semen Tonasa, hal ini berarti harapan masyarakat terkait pengimplementasian program CSR telah dilaksanakan dengan baik oleh PT Semen Tonasa sehingga hal tersebut membuat masyarakat menilai reputasi PT Semen Tonasa telah baik.

\section{UCAPAN TERIMA KASIH}

Penulis mengucapkan banyak termikasih kepada PT Semen Tonasa atas bantuannya selama penelitian ini berlangsung. Terimakasih yang sangat spesial untuk setiap orang yang telah menjadi responden.

\section{DAFTAR PUSTAKA}

Azheri, B. (2012). Corporate social responsibility: Dari voluntary menjadi mandatory. Jakarta: Rajawali Press.

Bahri, S. (2018). Metodologi penelitian bisnis. Yogyakarta: ANDI.

Bateman, T. S., \& Scott A. S. (2014). Manajemen: Kepemimpinan dan kerja sama dalam dunia yang kompetitif. Dialihbahasakan oleh Ratno Purnomo dan Willy Abdillah. Edisi ke-10. Buku 1. Jakarta Selatan: Salemba Empat.

Butterick, K. (2013). Pengantar public relations: Teori dan praktik. Dialihbahasakan oleh Nurul Hasfi. Edisi 1-2. Jakarta: Rajawali Pers.

Fahmi, I. 2017. Etika bisnis. Cetakan ke-4. Bandung: Alfabeta.

Fajar, M. 2010. Tanggung jawab sosial perusahaan di Indonesia. Yogyakarta: Pustaka Pelajar. 
Griffin, R. W., \& Michael, W. P. (2015). Bisnis internasional, sebuah perspektif manajerial. Dialihbahasakan oleh Diana Angelica, Annisa Puspita Dewi, Febriela Sirait, Dennies Anisa Balgis. Edisi 8. Jakarta Selatan: Penerbit Salemba Empat.

Hadi, N. (2011). Corporate social responsibility. Yogyakarta: Graha Ilmu.

Haerani, F. (2017). Strategi corporate social responsibility (csr) dalam rangka meningkatkan reputasi perusahaan (Dalam kajian aspek hukum bisnis). Jurnal Ilmu Hukum. (Online), 3 (http://lexlibrum.id/index.php/lexlibrum/article/view/99) diakses 4 Juni 2020.

Ishaq, R. E. (2017). Public Relations : Teori \& Praktik. Malang: Intrans Publishing.

Kabar.News. (2019, 14 Oktober). Dinilai tak serius masalah lingkungan, Semen Tonasa didemo. Diakses pada 2 Maret 2019, dari https://kabar.news/dinilai-tak-serius-masalah-lingkungansemen-tonasa-didemo.

Laporan tahunan PT Semen Tonasa. (2019).

Mardikanto, T. (2018). CSR (Corporate social responsibility) (Tanggungjawab sosial korporasi). Bandung: Alfabeta.

Margaretha, F., \&Ratna, I. (2014). Board diversity and gender composition on corporate social responsibility and firm reputation in indonesia. Jurnal Manajemen dan Kewirausahaan. (Online), 6 (http://203.189.120.189/ejournal/index.php/man/article/view/18880), diakses pada 30 Juni 2020.

Nova, F. (2011). Crisis public relations. Jakarta: Raja Grafindo Persada.

Peraturan Pemerintah Nomor 47 Tahun 2012 tentang tanggung jawab sosial dan lingkungan $\begin{array}{lllll}\text { perseroan terbatas. (2012). JDIH } & \text { BPK }\end{array}$ (https://peraturan.bpk.go.id/Home/Details/5260/pp-no-47-tahun-2012), diakses 1 Maret 2020.

Salinan peraturan menteri badan usaha milik negara republik indonesia nomor per02/MBU/04/2020 tentang perubahan ketiga atas peraturan menteri badan usaha milik negara Nomor Per-09/MBU/07/2015 Tentang program kemitraan dan program bina lingkungan badan usaha milik negara. (2020). Jaringan Dokumentasi dan Informasi Hukum Kementerian BUMN. (Online), (http://jdih.bumn.go.id/lihat/PER-02/MBU/04/2020), diakses 1 Juni 2020.

Sigit, T. H. (2012). Etika bisnis modern : Pendekatan pemangku kepentingan. Cetakan ke-1. Yogyakarta: Sekolah Tinggi Ilmu Manajemen YKPN.

Sugiarti, N. W. (2015). Pengaruh persepsi tentang corporate social responsibility terhadap reputasi perusahaan yang dimediasi oleh citra merek. e-jurnal manajemen Unud. (Online), 5 (https://ojs.unud.ac.id/index.php/Manajemen/article/download/12904/10306) diakses 4 Juni 2020.

Sugiyono. (2017). Metode penelitian kuantitatif, kualitatif, dan r\&d. Cetakan ke-9. Bandung: Alfabeta.

Syahriani, D., \& Mahmudi, S. (2018). Hubungan komunikasi corporate social responsibility dengan reputasi perusahaan. Jurnal Komunikasi Pembangunan. (Online), 2 (http://journal.ipb.ac.id/index.php/jurnalkmp/article/view/25121) diakses 4 Juni 2020.

Umar, Husein. (2011). Metode penelitian untuk skripsi dan tesis bisnis. Jakarta: PT Raja Grafindo Persada.

Undang-Undang Republik Indonesia Nomor 32 Tahun 2009 tentang perlindungan dan pengelolaan lingkungan hidup. (2009). JDIH BPK RI. (Online), (https://peraturan.bpk.go.id/Home/Details/38771/uu-no-32-tahun-2009), diakses 1 Maret 2020.

Undang-Undang Republik Indonesia Nomor 39 Tahun 1999 Tentang Hak Asasi Manusia. (1999). KOMNAS HAM Republik Indonesia. (https://www.komnasham.go.id/files/1475231474-uu-nomor-39-tahun-1999-tentang\%24H9FVDS.pdf), diakses 1 Maret 2020. 
Undang-Undang Republik Indonesia Nomor 40 Tahun 2007 tentang perseroan terbatas. (2007). JDIH BPK RI. (Online), (https://peraturan.bpk.go.id/Home/Details/39965/uu-no-40-tahun-2007), diakses 1 Maret 2020.

Wulandari, T. D. (2011). Pengaruh tanggung jawab perusahaan dalam menanggulangi krisis terhadap reputasi perusahaan. Jurnal Komunikasi. $\quad$ (Online), 9 (http://ojs.uajy.ac.id/index.php/jik/article/view/175), diakses 5 Juni 2020.

Yusdantara, I.K., \& Gede, B. R. (2015). Pengaruh corporate social responsibility terhadap reputasi perusahaan yang dimediasi oleh kepuasan pelanggan (Studi pada PT Xoca Cola amatil Denpasar). E-Jurnal Manajemen Unud. $\quad$ (Online), 5 (https://simdos.unud.ac.id/uploads/file_penelitian_1_dir/c5e33a9b8642af68af412bcb5767edcb.pdf) diakses 4 Juni 2020. 